\title{
Repliek: de Nederlandse morfologie in het Taalportaal
}

Ton van der Wouden, Geert Booij \& Jenny Audring

\section{Inleiding}

Het Taalportaal is een internetportaal dat grammaticale informatie (syntaxis, morfologie en fonologie) samenbrengt over het (hedendaags) Nederlands, het Fries en het Afrikaans. Dankzij een NWO-Groot subsidie (NWO Groot 175.010.2009.003) en aanvullende financiering vanuit Zuid-Afrika was het mogelijk om vanaf 1 januari 2011 een schat aan informatie over deze drie verwante Germaanse talen te verzamelen in een digitale omgeving, gratis toegankelijk voor iedere belangstellende (Van der Wouden et al. 2016). De metataal van het Taalportaal is het Engels, omdat het portaal zich primair richt op de internationale wetenschappelijke gemeenschap: met name het Nederlands is een buitengewoon goed beschreven taal die een belangrijke rol gespeeld heeft en nog steeds speelt in theoretische discussies binnen de taalwetenschap. Veel van de literatuur over de drie talen is evenwel gesteld in het Nederlands, het Fries of het Afrikaans, en er zijn weinig, misschien wel steeds minder, buitenlanders die die talen beheersen. Het Taalportaal beoogt, zonder te streven naar compleetheid, een voor de doelgroep bruikbare selectie van veel van de relevante feiten en visies weer te geven.

Elders in dit nummer laten collega's uit Gent (Arne Dhondt en Johan De Caluwe, hierna D\&C) en Amsterdam (Jan Don \& Fred Weerman, hierna D\&W) via een aantal casestudies hun licht schijnen op het deel van het Taalportaal dat gaat over de morfologie van het Nederlands. We zijn de collega's dankbaar voor hun opbouwende kritiek - het is altijd goed om feedback te krijgen - en we zijn de redactie van Nederlandse Taalkunde erkentelijk voor de mogelijkheid die zij ons biedt om daarop te reageren.

We zullen hier niet gedetailleerd ingaan op ieder punt dat wordt aangedragen door D\&C en D\&W; waar mogelijk zullen we in de toekomst die detailkritiek verwerken. Liever gaan we in op de vier hoofdlijnen van de kritiek die we zien.

\section{Het Taalportaal is nog niet af}

Terecht constateren de auteurs dat het Taalportaal nog niet af is. Administratief is het Taalportaalproject afgerond, in elk geval in die zin dat de financiering is afgelopen en dat NWO het eindverslag heeft goedgekeurd, maar er zitten nog aanzienlijke leemtes in. In de pijplijn zitten onder meer nog een grote hoeveelheid tekst over de syntaxis van Nederlandse 
samentrekking, de intonatie van het Nederlands, en over delen van de Friese morfologie; dwarsverwijzingen tussen syntaxis, morfologie, en fonologie kunnen nog worden verbeterd (zoals D\&C en D\&W geheel terecht opmerken), en het Afrikaanse gedeelte is nog lang niet klaar, al is maar het omdat het veel later begonnen is. De projectpartners Meertens Instituut, Fryske Akademy en Instituut voor de Nederlandse Taal zijn, in overleg met NWO en met de collega’s in Zuid-Afrika, overeengekomen dat zij ervoor zorgen dat het Taalportaal de komende jaren in de lucht blijft en waar nodig wordt bijgewerkt en aangepast. Ook de literatuurverwijzingen kunnen uiteraard nog worden verbeterd, en we hebben de ambitie om het portaal zo in te richten dat er zo veel mogelijk kan worden doorgeklikt naar (digitale versies) van de bronnen waarnaar verwezen wordt. Ook is er een beginnetje gemaakt met het deels manueel, deels automatisch verrijken van de tekst met zoekopdrachten in diverse soorten tekstcorpora, variërend van ruwe internetdata naar rijk geannoteerde treebanks met bijbehorende zoekinstrumenten (Van der Wouden et al. 2017). Zo mogelijk zullen we doorgaan met deze verrijking.

\section{Wat het Taalportaal (niet) is}

De auteurs hebben in hun commentaar de neiging het Taalportaal te overvragen. Het kan niet een complete beschrijving van alle details zijn, en het heeft ook niet die ambitie. Daarom is het voor onderzoekers soms nodig dat ze verder gaan kijken in de genoemde literatuur (die af en toe mogelijk zelf nog wel aanvulling behoeft). Een deel van die literatuur is overigens in het Nederlands en is dus alleen relevant voor een deel van de gebruikers van het Taalportaal (dat geldt ook voor De Haas \& Trommelen 1993). Een mogelijkheid voor verdere vervolmaking en uitbreiding van informatie voor lezers die het Nederlands wel beheersen, is een koppeling tussen Taalportaal en de nieuwe ANS.

Voor de Nederlandstalige én de niet-Nederlandstalige lezer biedt het Taalportaal een schat aan informatie, maar het kan niet alle bronnen vervangen. Het is bijvoorbeeld geen woordenboek, zodat voor informatie over bijvoorbeeld de betekenis van individuele woorden een andere bron moet worden geraadpleegd. Hetzelfde geldt voor de literatuurverwijzingen: het Taalportaal biedt geen vervanging voor vakbibliografieën zoals de BNTL $^{1}$ of de Bibliographie Linguistique ${ }^{2}$. Het Taalportaal is ook geen grammatica voor iedereen: het richt zich primair op taalkundigen. De vragen van andere taalliefhebbers en -professionals worden

\footnotetext{
${ }^{1}$ http://www.bntl.nl/bntl/.

${ }^{2}$ http://bibliographies.brillonline.com/browse/linguistic-bibliography.
} 
mogelijk eerder en beter beantwoord door de ANS (die inmiddels herzien wordt) of websites zoals www.taaladvies.net.

\section{Het Taalportaal is niet het werk van één auteur}

Terecht wordt geobserveerd dat er soms een verschil is tussen de behandeling van hetzelfde verschijnsel in het syntactische en het morfologische deel (bijvoorbeeld waar het gaat om het achtervoegsel -ing). Dit weerspiegelt de ontstaansgeschiedenis van het Taalportaal, waar we hier verder niet op in hoeven te gaan, en het feit dat er nu eenmaal verschillende auteurs aan het project hebben gewerkt. Dergelijke verschillen zijn niet aanvaardbaar binnen één wetenschappelijk artikel, maar zijn minder problematisch voor een informatiemedium als het Taalportaal: het Taalportaal beoogt niet de (of zelfs maar een) waarheid weer te geven, maar veeleer een overzicht van de bestaande inzichten en analyses te bieden, en een wegwijzer te zijn voor onderzoekers die verder willen met een onderwerp.

\section{Het Taalportaal hangt niet één theorie aan}

Zonder metataal ben je als taalkundige sprakeloos, en een theorieneutrale beschrijving van taalfenomenen is een onbereikbaar ideaal. Gegeven dat het Taalportaal beoogt een overzicht te geven van de voornaamste inzichten en analyses betreffende het Nederlands, ligt het voor de hand dat er terminologie gehanteerd wordt uit verschillende grammaticale kaders. Een gevolg is dat er wel eens verschillende soorten begrippen door elkaar gebruikt worden, zowel uit bijvoorbeeld de generatieve grammatica als uit de constructiegrammatica en de semantiek. We hebben er wel naar gestreefd dat op zo'n manier te doen dat de gehanteerde termen en begrippen ook buiten de specifieke theorie begrijpelijk zijn.

\section{Tot besluit}

Het Taalportaal is een nieuw soort bron van taalkundige informatie: nergens ter wereld bestaat er zo’n portaal dat zoveel fonologische, morfologische én syntactische informatie over drie verwante talen op een min of meer parallelle wijze aanbiedt, waarbij het geheel meer is dan de som van de delen. Zoals ieder nieuw ding heeft ook het Taalportaal te kampen met kinderziektes. We hebben begrip voor veel van de detailkritiek, en met de kennis van nu zouden we het Taalportaal ongetwijfeld enigszins anders hebben opgezet. Maar feit blijft dat het Taalportaal niet de pretentie heeft het laatste woord te zijn in grammaticale zaken; hopelijk kan het voor veel, met name buitenlandse taalkundigen, wel de eerste bron van informatie zijn, een stevige basis waarop ze hun vervolgonderzoek kunnen grondvesten. Het 
gegeven dat het Taalportaal al veelvuldig wordt gebruikt, is zeer bemoedigend. En voor aanvullingen, suggesties en kritiek staan we altijd open, bijvoorbeeld via de contactknop rechts bovenaan iedere pagina.

\section{Referenties}

de Haas, Wim \& Mieke Trommelen (1993). Morfologisch handboek van het Nederlands: een overzicht van de woordvorming. Den Haag: SDU.

van der Wouden, Ton e.a. (2016). Het Taalportaal. Een nieuwe wetenschappelijke grammatica voor het Nederlands en het Fries (en het Afrikaans). Nederlandse Taalkunde 21(1), 157-168.

van der Wouden, Ton, Gosse Bouma, Matje van de Camp, Marjo van Koppen, Frank Landsbergen \& Jan Odijk (2017). Enriching a scientific grammar with links to linguistic resources: the Taalportaal0 In: Jan Odijk \& Arjen van Hessen (red.), CLARIN in the Low Countries. London: Ubiquity Press, 299-310.

\section{Over de auteurs}

Ton van der Wouden, Meertens Instituut

E-mail: ton.van.der.wouden@meertens.knaw.nl

Geert Booij, Universiteit Leiden

E-mail: g.e.booij@hum.leidenuniv.nl

Jenny Audring, Universiteit Leiden

E-mail: j.audring@hum.leidenuniv.nl 